\title{
Yoga Pranayama Dhiirga Swasam with Sukhasana Position on Reducing Blood Pressure in the Elderly
}

\author{
Nurmai Lindasari ${ }^{1 *}$, Enik Suhariyanti ${ }^{1}$, Sri Margowati $^{1}$ \\ ${ }^{I}$ Department of Health Science, Universitas Muhammadiyah Magelang, Magelang, Indonesia \\ *Corresponding author. Email: ndalinda508@gmail.com
}

\begin{abstract}
The deterioration of the function of organs especially in the elderly causes the elderly to be prone to attacks by various chronic diseases, including Hypertension. Non-pharmacological therapies that are used include yoga. This study is going to determine the effect of Yoga Pranayama Dhiirga Swasam with Sukhasana position on reducing blood pressure in the elderly. The method used in this paper is Quasy Experiment, with a non-randomized design control group pre-test post-test design. The sample size was 44 people, divided into a control group and an experimental group. The results of the Wilcoxon test in the intervention group got the results of $p=0.014(\alpha<0.05)$ and in the control group the results of $p=0.317(\alpha>0.05)$, there were significant influences between before and after doing the Yoga Pranayama Dhiirga Swasam action with Sukhasana Position in the intervention group. The difference to the 2 groups indicated by the results of the average decrease in systolic and diastolic pressure. It implies that Yoga Pranayama Dhiirga Swasam with Sukhasana position effects on reducing high blood pressure in the elderly.
\end{abstract}

Keywords: blood pressure, yoga, Dhiirga Swasam

\section{INTRODUCTION}

Hypertension becomes a Silent Killer because in most cases it does not show any symptoms and one day hypertension can be a stroke and heart attack that causes the sufferer to die. Even headaches that often occur as indicators of hypertension do not occur in some people or are considered a mild complaint that will heal by itself [1]. Elderly often affected by hypertension caused by stiffness in the arteries so that blood pressure tends to increase [2]. Hypertension in Indonesia is the sixth highest non-communicable disease [3]. Central Java is one of the provinces in Indonesia which has a relatively high level of hypertension compared to other regions, which is $8.2 \%$. The region that has the highest level of hypertension in Indonesia is North Sulawesi with a hypertension level of $13.2 \%$. The level of hypertension in Central Java is dominated by women with a prevalence of $36.9 \%$ compared to men who are only $31.3 \%$ with the highest average age of hypertension sufferers of 75 years and over ie $69.5 \%$ and the lowest prevalence of ages 18-24 namely $13.2 \%$ [4]. In Magelang District, hypertension is the highest non-communicable disease with the number of hypertension sufferers at 26,096, whereas for the puskesmas and sub-districts in the district of Magelang, which has a high number of hypertension sufferers, one of them is Srumbung sub-district with a number of hypertension sufferers, namely 2096 [4].

Hypertension becomes very dangerous in the elderly because excessive blood pressure causes various complications of diseases such as heart failure, kidney disorders, erectile dysfunction, vision disorders, cognitive impairment or dementia [5]. In addition, the most severe complication of hypertension can cause death [6]. Several studies have reported that uncontrolled hypertension can cause a stroke risk seven times greater, a risk six times greater than congestive heart failure and a risk three times greater than a heart attack [5].

Management of hypertension can be done pharmacologically and non-pharmacologically [7]. Management of pharmacological hypertension that is using chemical drugs [8], and management of hypertension in a non-pharmacological manner, namely deep breathing, progressive relaxation of aerobic gymnastics, yoga and music therapy [7]. Yoga is recommended for people with hypertension because it has a relaxing effect that can improve blood circulation throughout the body. Smooth blood circulation will indicate good heart work [9].

This study is going to determine the effect of Yoga Pranayama Dhiirga Swasam with Sukhasana position on reducing blood pressure in the elderly. The result of this study is expected to be a consideration for the elderly.Thus, By mastering breathing techniques as well as mastering emotions and thoughts through gentle and regular breathing that will make the mind become calmer and the body becomes more relaxed Yoga Pranayama Dhiirga Swasam with Sukhasana position effects on reducing high blood pressure.

\section{RESEARCH METHODS}

In this study using a Quasi Experiment research design. The design used in this study is a non-equivalent control group or non-randomized control group pretest posttest design, which is a design consisting of a control group and an experimental group, other than that in the grouping of sample members in the control and experiment groups are not done randomly or randomly [10]. 
Before giving Yoga Pranayama Dhiirga Swasam with the position of Sukhasana, blood pressure in the elderly with hypertension in the intervention and control groups was measured, then the action of giving Yoga Pranayama Dhiirga Swasam with the position of Sukhasana in the intervention group. Independent variable or Independent variable is a variable that influences or determines the value of other variables [11].

The data collection process began with data collection at the Srumbung Community Health Center to obtain a population in the study of 161 elderly people, after that the sample calculation used the mean difference, independent group so that the sample was 42 elderly, then the sampling calculation was done using purposive sampling and in get a proportional sample of 44 elderly people. Of the 44 elderly people were divided into intervention groups and control groups based on the location of the area (hamlet) to facilitate conducting research, with each group totaling 22 elderly.

Respondents were given Yoga Pranayama Dhiirga Swasam with the position of Sukhasana for 3 times a week for 2 weeks with a time of 30 minutes. Procedure for Provision of Pranayama Dhiirga Swasam Yoga with Sukhasana position. Before doing a Yoga session it is recommended to warm up. Warming aims to increase the flexibility of muscles and joints so that a movement will be easier to do. Besides warming up is done to avoid the body from the risk of injury when practicing[12].

Steps to do Yoga Pranayama Dhiirga Swasam with Sukhasana position:

\subsection{Preparation Stage}

a. Prepare a Yoga mat or Carpet.

b. Wear comfortable and loose clothing.

c. Do not wear footwear (Take off footwear).

d. Release the tension.

e. Full of awareness

f. Create a calm atmosphere.

\subsection{Warming Stage}

a. Prepare a standing position, feet shoulder width apart, place your hands on the waist.

b. Tilt your head up and down several times.

c. Looked to the right and left for several times.

d. Turn the neck clockwise and counterclockwise.

e. Twisting Shoulder

f. Move the backbone to the right and left.

g. Stretch your knees, feet and toes.

\subsection{Yoga Sessions}

a. Set the sitting position, namely Sukhasana. In a way:

1) Sit on the floor or Mattress.

2) Cross the legs, and place the feet below the knee.

3) Hold hands around the knee.

4) Keep the body and head straight.

b. Breathe (Pranayama) Dhiirga Swasam by:
1) Place one hand on the abdomen or stomach and the other hand on the thorax or chest (Keep the backbone upright and both shoulders comfortable or relaxed).

2) Inhale, feel the breath flow and develop the abdominal area, then stretch the ribs and all parts of the chest, then shrug.

3) When exhaling, the air will deflate starting from the bottom of the lungs, ribs, and finally the entire chest.

4) Always breathe through your nose with your mouth closed and breathe slowly and rhythmically.

\subsection{Cooling Phase}

Straighten your legs forward, tighten your toes up then down, rotate outward, rotate inward, shake your knees.

\section{RESULTS AND DISCUSSION}

\subsection{Distribution of Blood Pressure Before and After the Intervention Group.}

The empirical findings of the study are presented in this section. The analysis begins by explaining the changes of blood pressure, both groups, before and after given intervention Yoga Pranayama Dhiirga Swasam with the position of Sukhasana. Then, we analyze Yoga Pranayama Dhiirga Swasam with the position of Sukhasana effect on blood pressure in the elderly.

Blood pressure distribution before and after, in the intervention group can be seen in the table below:

Table 1 Distribution of Blood Pressure Before to the Elderly with Hypertension Intervention Group in Bringin Village, Srumbung District in 2019

\begin{tabular}{|c|c|c|c|c|c|}
\hline \multirow[t]{2}{*}{ No } & \multirow[t]{2}{*}{ Blood Pressure } & \multicolumn{2}{|c|}{ Systole } & \multicolumn{2}{|c|}{ Diastole } \\
\hline & & $\mathrm{N}$ & $\%$ & $\mathrm{~N}$ & $\%$ \\
\hline 1 & Mild & 10 & 45.4 & 19 & 86.4 \\
\hline 2 & Moderate & 12 & 54.6 & 3 & 13.6 \\
\hline Total & & 22 & 100 & 22 & 100 \\
\hline
\end{tabular}

Based on table 1 it can be seen that cystolic blood pressure is 10 people $(45.4 \%)$, and cystolic blood pressure is 12 people $(54.6 \%)$. Whereas in diastolic blood pressure, mild amounted to 19 people $(86.4 \%)$ and diastolic blood pressure, moderate amounted to 3 people $(13.6 \%)$.

Table 2 Distribution of Blood Pressure After the Elderly with Hypertension Intervention Group in Bringin Village, Srumbung District in 2019

\begin{tabular}{|cllrrr|}
\hline No & \multirow{2}{*}{ Blood Pressure } & \multicolumn{2}{c}{ Systole } & \multicolumn{2}{c|}{ Diastole } \\
& & $\mathrm{N}$ & $\%$ & $\mathrm{~N}$ & $\%$ \\
\hline 1 & Mild & 14 & 63.6 & 22 & 100 \\
2 & Moderate & 8 & 36.3 & & \\
\hline Total & & 22 & 100 & 22 & 100 \\
\hline
\end{tabular}


Based on table 2 it can be seen that cystolic blood pressure, mild is 14 people $(63.6 \%)$ and cystolic blood pressure, moderate is 8 people $(36.4 \%)$. Whereas in diastolic blood pressure, mild amounted to 22 people $(100 \%)$.

\subsection{Distribution of Blood Pressure Before and After the Control Group.}

Blood pressure distribution before and after, in the control group can be seen in the table below:

Table 3 Distribution of Blood Pressure Before the Elderly with Hypertension Control Group in the Village of Bringin Srumbung District in 2019

\begin{tabular}{|cllclr|}
\hline No & Blood Pressure & \multicolumn{2}{c}{ Systole } & \multicolumn{2}{c|}{ Diastole } \\
& & $\mathrm{N}$ & $\%$ & $\mathrm{~N}$ & $\%$ \\
\hline 1 & Mild & 8 & 36.4 & 16 & 72.7 \\
2 & Moderate & 14 & 63.6 & 6 & 27.3 \\
\hline Total & & 22 & 100 & 22 & 100 \\
\hline
\end{tabular}

Source: Primary data processed, 2019

Based on table 3 it can be seen that the distribution of systolic blood pressure, mild amounted to 8 people (36.4\%), systolic blood pressure, moderate amounted to 14 people $(63.6 \%)$. Whereas in diastole blood pressure, mild amounted to 16 people $(72.7 \%)$, diastole blood pressure, moderate amounted to 6 people $(27.3 \%)$.

Table 4 Distribution of Blood Pressure After the Elderly with Hypertension Control Group in Bringin Village, Srumbung District in 2019

\begin{tabular}{|cccccc|}
\hline No & \multirow{2}{*}{ Blood Pressure } & \multicolumn{2}{c}{ Systole } & \multicolumn{2}{c|}{ Diastole } \\
& & $\mathrm{N}$ & $\%$ & $\mathrm{~N}$ & $\%$ \\
\hline 1 & Mild & 7 & 31.8 & 14 & 63.7 \\
2 & Moderate & 15 & 68.2 & 8 & 36.4 \\
\hline & Total & 22 & $100 \%$ & 22 & $100 \%$ \\
\hline & Source: Primary data processed, 2019 & \multicolumn{3}{c}{}
\end{tabular}

Based on table 4 it can be seen that the distribution of systolic blood pressure, mild amounted to 7 people $(31.8 \%)$, systolic blood pressure, moderate amounted to 15 people $(68.2 \%)$. While diastole blood pressure, mild amounted to 14 people $(63.7 \%)$ and diastole blood pressure, moderate amounted to 8 people $(36.4 \%)$.

\subsection{Differences in Blood Pressure Before and After Being Given Yoga Treatment Pranayama Dhiirga Swasam with Sukhasana Position in the Intervention and Control Groups.}

Table 5 The Difference in Blood Pressure Before and After the Treatment of Pranayama Dhiirga Swasam Yoga with the Position of Sukhasana in the Intervention Group and Blood Pressure at the Beginning and End in the Control Group

\begin{tabular}{|lcrrr|}
\hline & \multicolumn{2}{c}{ Intervention $(\mathbf{n}=\mathbf{2 2})$} & \multicolumn{2}{c|}{ Control $(\mathbf{n = 2 2})$} \\
\hline & Before & After & Beginning & End \\
\hline The mean & 155.680 & 151.360 & 160.000 & 160.680 \\
& 93.180 & 91.820 & 94.320 & 94.550 \\
Sd & 9.673 & 9.659 & 10.351 & 10.499 \\
& 3.634 & 2.462 & 4.168 & 4.056 \\
P value & & 0.014 & 0.317 & \\
\hline
\end{tabular}

*Wilcoxon's test

Based on the results of the analysis of table $\mathrm{V}$ found that the $p$ value in the intervention group before and after (systole, diastole) is 0.014 , which means that $p$ value $<0.05$, it can be concluded that there is an influence on the decrease in blood pressure in the intervention group, before and after the intervention was given. While in the control group that is blood pressure at the beginning and end (systole-, diastole) the results obtained are $p$ value 0.317 , which means $p$ value $>0.05$, so it can be concluded that there is no influence on the decrease in blood pressure in the control group at the beginning and at the end.

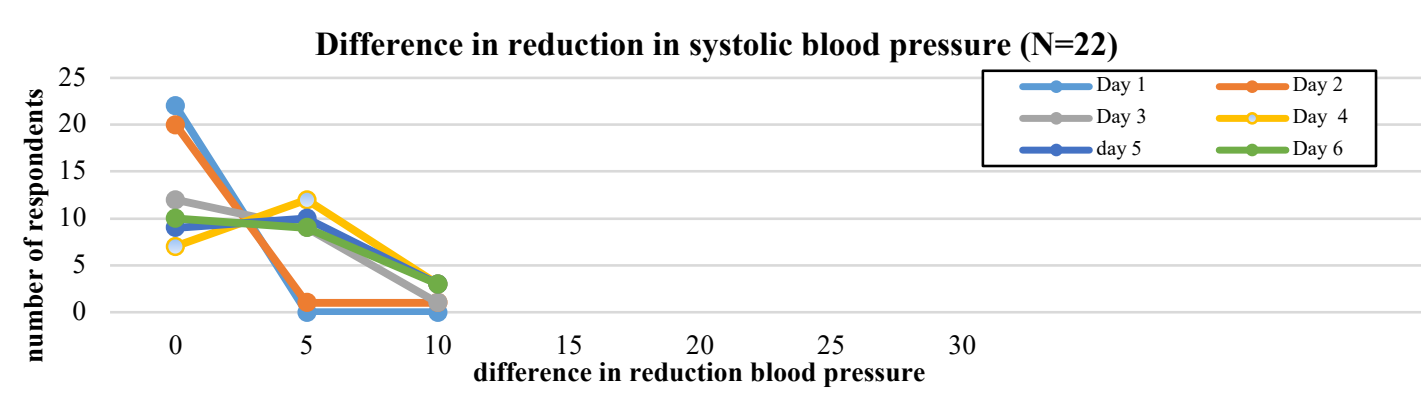

Figure 1 Difference in changes in systolic blood pressure in the intervention group 
systole blood pressure reduction occurs in respondents with different amounts.
Based on Figure 1 it can be seen that the difference in systole blood pressure reduction by $0 \mathrm{mmHg}, 5 \mathrm{mmHg}$ and $10 \mathrm{mmHg}$ on days 1 through 6 , where each difference in

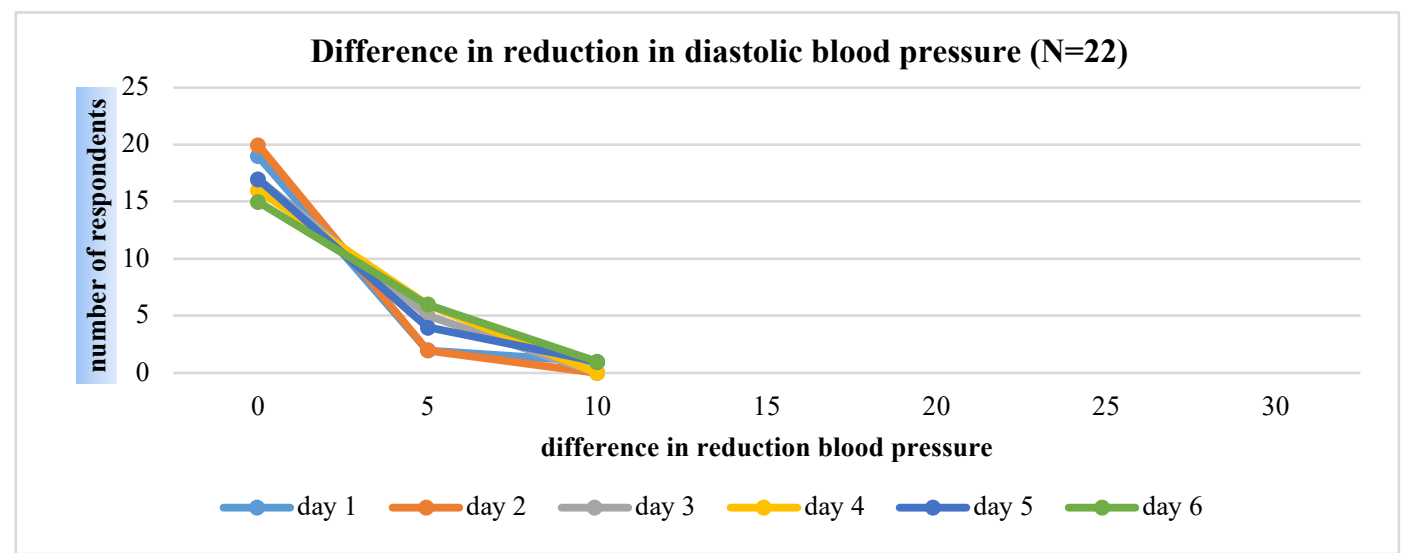

Figure 2 Difference in changes in diastolic blood pressure in the intervention group

Based on figure 2 it can be seen that the difference in diastole blood pressure reduction by $0 \mathrm{mmHg}, 5 \mathrm{mmHg}$ and $10 \mathrm{mmHg}$ on days 1 through 6 , where each difference in diastole blood pressure reduction occurs in respondents with different amounts.

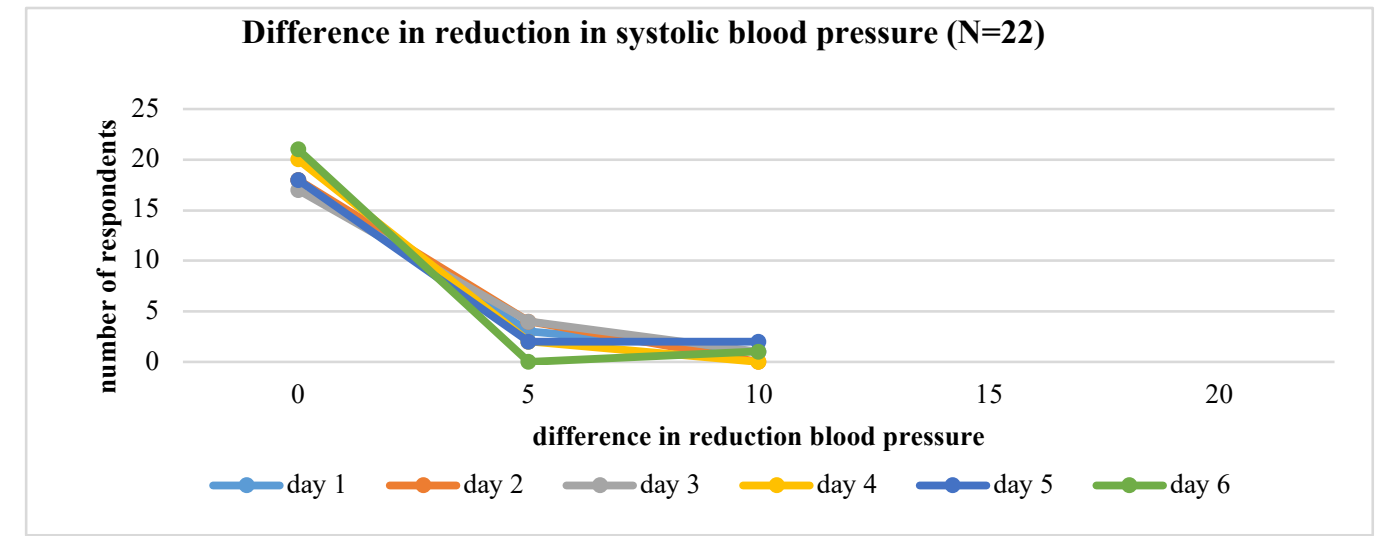

Figure 3 Difference in changes in systolic blood pressure in the control group

Based on figure 3 it can be seen that the difference in changes in systolic blood pressure by $0 \mathrm{mmHg}, 5 \mathrm{mmHg}$ and $10 \mathrm{mmHg}$ on days 1 through 6 , where each difference in changes in systolic blood pressure occurs in respondents with different amounts.

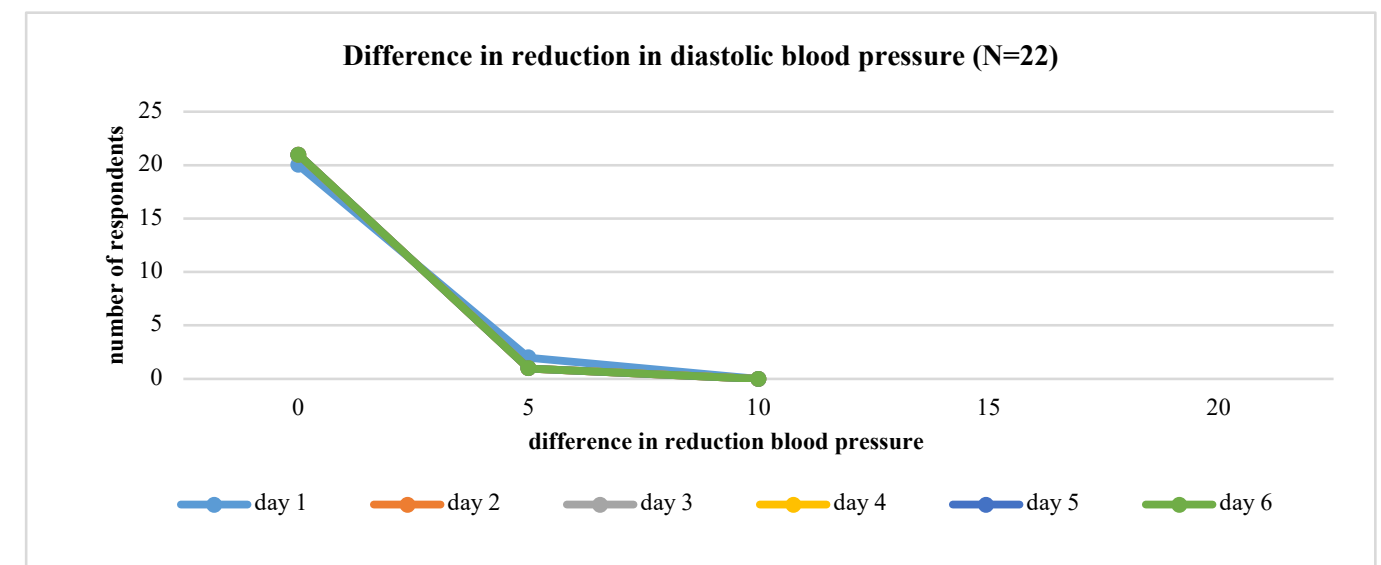

Figure 4 Difference in changes in diastolic blood pressure in the control group 
Based on figure. 4 it can be seen that the difference in diastole blood pressure changes by $0 \mathrm{mmHg}, 5 \mathrm{mmHg}$ and $10 \mathrm{mmHg}$ on days 1 through 6 , where each difference in changes in diastole blood pressure occurs in respondents with different amounts.
Comparison of systolic and diastolic blood pressure in the control and intervention groups can be seen in the table below:

Table 6 Blood Pressure Difference Test On Intervention And Control Groups

\begin{tabular}{|ccccc|}
\hline & $\begin{array}{c}\text { Intervention }(\mathbf{N}=\mathbf{2 2}) \\
\text { Mean }\end{array}$ & $\begin{array}{c}\text { Control }(\mathbf{N}=\mathbf{2 2}) \\
\text { Mean }\end{array}$ & Z & P value \\
\hline Systole & 17.16 & 27.84 & -2.808 & 0.005 \\
Diastole & 19.05 & 25.95 & -1.980 & 0.048 \\
\hline *Mann-Whitney & & &
\end{tabular}

Based on the test results, the difference in blood pressure between systole and diastole is obtained that the $p$ value $<0.05$ then Ho is rejected and $\mathrm{Ha}$ is accepted. The results concluded that there was a significant effect on the difference in systolic and diastolic blood pressure in the control and intervention groups.

The results

In the control group it was found that the mean systolic and diastolic blood pressure at the beginning and at the end of the significant values showed $p>0.05$. So that Ho results are accepted, $\mathrm{Ha}$ is rejected. This means that there was no significant decrease in blood pressure at the beginning and at the end of the control group, this could be due to the control group not being given treatment in the form of Yoga Pranayama Dhiirga Swasam with the Sukhasana position. However, blood pressure in the control group tended to be stable or increased. The possibility of increasing blood pressure in each individual from days 1 to 6 can be influenced by factors that can affect blood pressure such as excessive salt consumption, alcohol consumption, smoking, obesity, age, sex, family history with hypertension and ethnicity [13]. Based on the amount of blood pressure systole and diastole at the beginning and at the end, there were 6 respondents who experienced a slight increase in blood pressure both cystolic and diastolic, the increase was in the range of $5-10 \mathrm{mmHg}$.

Pressure difference blood pressure before and after treatment was given to the intervention group using the Wilcoxon test and the statistical test results were $\mathrm{p}$ value $0.001<0.05$, which means that in the intervention group Ho was rejected and Ha was accepted. It can be concluded that there is a significant decrease in the average systolic and diastolic blood pressure before and after the Yoga Pranayama Dhiirga Swasam treatment with Sukhasana position.

\section{CONCLUSION}

Based on the results of research and discussion on the Effects of Pranayama Dhiirga Swasam Yoga on Hypertension in the elderly in Bringin Village, Srumbung District, Magelang District, the conclusion that can be drawn is the identification of blood pressure before and after being given Yoga Pranayama Dhiirga Swasam with the position of Sukhasana with the difference in blood pressure reduction namely $5 \mathrm{mmHg}$ to $10 \mathrm{mmHg}$.
In the control group did not experience a decrease in blood pressure, at the time of blood pressure examination at the beginning and at the end of that is for 6 times in 2 weeks. There is the influence of Yoga Pranayama Dhiirga Swasam with the position of Sukhasana on hypertension in the elderly.

This research is expected to provide information to the public about the benefits of Pranayama Dhiirga Swasam Yoga with the position of Sukhasana which can be used as a non-pharmacological therapy to overcome hypertension. Researchers are well aware of the limitations of this study due to factors that can influence blood pressure reduction is not optimal, cannot be controlled by researchers in the control and intervention groups, such as excessive salt consumption, smoking habits, excessive coffee consumption and stress.

\section{ACKNOWLEDGMENT}

We would like to thank the health sciences faculty of the Muhammadiyah University of Magelang for material and non-material donations to enable us to do this research.

\section{AUTHOR CONTRIBUTIONS}

Conceptualization (E.S, S.M); Material research preparation (E.S, N. L); Methodology (S.M, N.L); Data collecting (N.L); Data analysis and visualization (N.L, E.S, S.M); Writing - original draft (E.S, N.L); Presentation (E.S).

\section{REFERENCES}

[1] Kurniadi, H., \& Nurrahmani, U, Stop Diabetes Hipertensi Kolesterol Tinggi Jantung Koroner. Istana Media, Yogyakarta, 2015.

[2] Seke, P. A., Bidjuni, H. J., \& Lolong, J, Hubungan Kejadian Stress Dengan Penyakit Hipertensi Pada Lansia Di Balai Penyantunan Lanjut Usia Senjah Cerah Kecamatan Mapanget Kota Manado, E-Journal Keperawatan (e-Kp), Volume 4(Nomor 2), 1-5, 2016.

[3] Hidayah, N., Damanik, S. R. H., \& Elita, V. Perbandingan Efektivitas Terapi Musik Klasik Dengan 
Niten Nogotirto, Gamping, Sleman, Yogyakarta, Naskah Publikasi, Program Studi Ilmu Keperawatan Sekolah Tinggi Ilmu Kesehatan 'Aisyiyah, 2015.

[4] Kementrian Kesehatan Republik Indonesia, Hasil Utama RISKESDAS 2018, Kementrian Kesehatan Republik Indonesia Badan Penelitian dan Pengembangan Kesehatan, 2018.

[5] Fahmi, M. M., \& Sari, S. M, The effectiveness of yoga to decrease blood pressure in elderly with hypertension in tresna werdha khusnul khotimah nursing homes pekanbaru, Riau International Nursing Conference, 2015.

[6] Andjani, T. A. D, Perbedaan Pengaruh Masase Punggung Dan Slow Stroke Back Massage (SSBM)

Terhadap Tekanan Darah Pada Lansia Dengan Hipertensi Di UPT PSLU Jember, Skripsi, 2016.

[7] Astuti, E. P., Suwardianto, H., \& Yuliantin, N, 5th Octave Music Therapy Menurunan Tekanan Darah Terhadap Penderita Hipertensi, Jurnal Penelitian Keperawatan 2, 2016.

[8] Ovianasari, A, Pengaruh latihan yoga terhadap tekanan darah pada lansia penderita hipertensi di Dusun
[9] Nurwidya, M. D, Pengaruh Yoga Terhadap Tekanan Darah Pada Penderita Hipertensi Di Purwodiningratan, Skripsi, 2018.

[10] Notoatmodjo, S, Metode Penelitian Kesehatan, PT Rineka Cipta, Jakarta, 2018.

[11] Nursalam, Metodologi Penelitian Ilmu Keperawatan Pendekatan Praktis Edisi 4, Salemba Medika, Jakarta, 2017.

[12] Sindhu, P, Panduan Lengkap Yoga : Untuk Hidup Sehat Dan Seimbang, Qanita, Bandung, 2015.

[13] Septiawan, T., Permana, I., \& Yuniarti, F. A., Studi Deskriptif Karakteristik Pasien Hipertensi Di Wilayah Kerja Puskesmas Gamping II Yogyakarta, Prosiding Konferensi Nasional Ke- 7 Asosiasi Program Pascasarjana Perguruan Tinggi Muhammadiyah 'Aisyiyah (APPPTMA), 2018. 